\title{
Objectives and Strategies of the International Photovoltaic Program Plan
}

\author{
Dennis Costello \\ David Posner \\ Robert Koontz \\ Patricia Heiferling \\ Solar Energy Research Institute
}

Paul Carpenter

Lewis Perelman

Jet Propulsion Laboratory
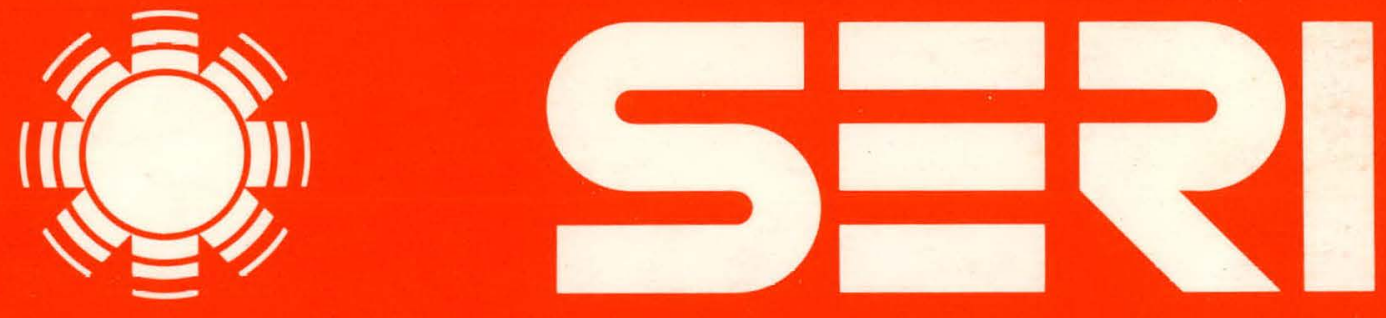

Solar Energy Research Institute

A Division of Midwest Research Institute

1536 Cole Boulevard

Golden, Colorado 80401

Operated for the

U.S. Department of Energy under Contract No. EG-77-C-01-4042

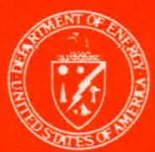




\section{DISCLAIMER}

This report was prepared as an account of work sponsored by an agency of the United States Government. Neither the United States Government nor any agency Thereof, nor any of their employees, makes any warranty, express or implied, or assumes any legal liability or responsibility for the accuracy, completeness, or usefulness of any information, apparatus, product, or process disclosed, or represents that its use would not infringe privately owned rights. Reference herein to any specific commercial product, process, or service by trade name, trademark, manufacturer, or otherwise does not necessarily constitute or imply its endorsement, recommendation, or favoring by the United States Government or any agency thereof. The views and opinions of authors expressed herein do not necessarily state or reflect those of the United States Government or any agency thereof. 


\section{DISCLAIMER}

Portions of this document may be illegible in electronic image products. Images are produced from the best available original document. 


\author{
Printed in the United States of America \\ Available from: \\ National Technical Information Service \\ U.S. Department of Commerce \\ bL85 Port Royal Road \\ Springfield, VA 22161 \\ Price: \\ Microfiche $\$ 3.00$ \\ Printed Copy $\$ 4.50$
}

NO'IL'LE

This report was prepared as an account of work sponsored by the United States Government. Neither the United States nor the United States Department of Energy, nor any of their employees, nor any of their contractors, subcontractors, or their employees, makes any warranty, express or implied, or assumes any leyal liability or responsibility for the accuracy, completeness or usefulness of any information, apparatus, product or process disclosed, or represents that its use would not infringe privately owned rights. 
DISCLAIMER

Whe United States Governmen. This book was prepared as an account of work sponsored by an agener ofy of their employees. makes any The weither tre express os implied, or assumes any legal liabitus, product, of process disclosed, of complecenass, or usefulness of ony information, apped rights. Feterence herein to any spectice

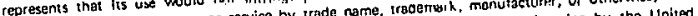

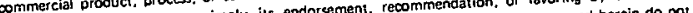

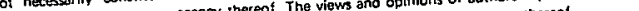

DENNIS COSTELLO

DÁVID POSNER

ROBERT KOONTZ

PATRICIA HEIFERLING

SOLAR ENERGY RESEARCH INSTITUTE

PAUL CARPENTER

LEWIS PERELMAN

JET PROPULSION LABORATORY

JULY 1979

PREPARED UNDER TASK NO. 5224

Solar Energy Research institute

1536 Cole Boulevard

Golden, Colorado 80401

A Division of Midwest Research Institute

Prepared for the

U.S. Department of Energy

Contract No. EG $77 \cdot C \cdot 01 \cdot 404$ ? 


\section{THIS PAGE}

WAS INTENTIONALLY

LEFT BLANK 
$(i)$

\section{FOREWORD}

This report is the first step in preparing an International Photovoltaic Program Plan for the U.S. Department of Energy. The plan is called for in the Solar Photovoltaic Energy Research, Development, and Demonstration Act of 1978. The final plan will be completed by November 5, 1979.

The report was prepared under SERI Task 5226. This report and the final plan represent a cooperative effort between SERI and the Photovoltaics Lead Center at the Jet Propulsion Laboratory. Comments from the members of the International Solar Commercialization Working Group helped guide the report.

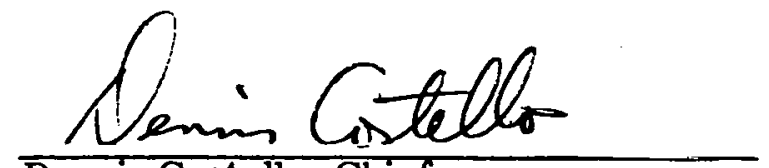

Dennis Costello, Chief

Economic Analysis Branch

Approved for:

SOLAR ENERGY RESEARCH INSTITUTE

Melvin K. Simmons, Assistant Director

Analysis Division 


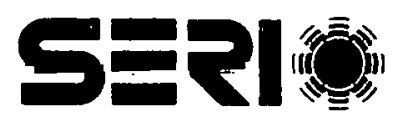




\section{SUMMARY}

The Solar Photovoltaic Energy Research, Development, and Demonstration (RD\&D) Act of 1978 calls for the Secretary of the U.S. Department of Energy (DOE) to prepare a plan to demonstrate photovoltaic systems in other nations and to facilitate the widespread use of these systems. This report describes the objective of the International Photovoltaic Program Plan (Section 4), the strategies that will be used in the plan (Section 5), and the approach that is being taken to prepare the plan (Section 3). Background on photovoltaic technology and markets and the DOE domestic photovoltaic effort is also provided (Section 2).

The Photovoltaic RD\&D Act and available photovoltaic market research indicate that international markets will be the largest markets for photovoltaic systems during the next several years. DOE has an ongoing research and development program directed at making photovoltaic systems cost effective with electric utility power in the United States. However, photovoltaic systems are not likely to compete in major U.S. energy markets until the late 1980s. In the preceding years, international markets could stimulate the growth of the U.S. photovoltaic industry and help this industry achieve reductions in photovoltaic system costs. The International Photovoltaic Program Plan will complement the DOE domestic activities to stimulate international markets.

A number of national and international benefits could result if the objective of accelerating the widespread use of photovoltaic systems in international markets is realized. A primary benefit is that foreign markets may help stabilize the U.S. photovoltaic industry and foster its expansion. Other benefits include contributions to the advancement of developing countries, reductions in world oil imports, and improvements in the U.S. balance of trade.

Strategies to be addressed in the plan are photovoltaic system demonstrations, systems development, information gathering and dissemination, financial incentives, and administrative actions. A critical aspect of the plan will be the coordination of selected programs and the monitoring and asesesment of the plan's results.

SERI, with support from the Photovoltaics Lead Center at the Jet Propulsion Laboratory, is responsible for preparing the International Photovoltaic Program Plan for DOE. Anulyses of international markets, international financial institutions, foreign competition, international marketing experiences of other U.S. industries, and system development needs have been initiated to support the plan. The Departments of Energy, Commerce, State, and Treasury, the Agency for International Development, the Peace Corps (ACTION), as well as other relevant federal agencies will be closely involved in preparation of the plan. SERI will deliver a draft plan to DOE on September 6, 1979. A revised draft will be delivered on October 4. The final plan will be submitted by DOE to Congress on November 5, 1979. 


$$
\text { S=R| }
$$




\section{TABLE OF CONTENTS}

1.0 Introduction $\ldots \ldots \ldots \ldots \ldots \ldots \ldots \ldots \ldots \ldots \ldots \ldots \ldots \ldots \ldots \ldots \ldots \ldots \ldots \ldots \ldots$

$2.0 \quad$ Background $\ldots \ldots \ldots \ldots \ldots \ldots \ldots \ldots \ldots \ldots \ldots \ldots \ldots \ldots \ldots \ldots \ldots \ldots \ldots \ldots \ldots \ldots \ldots . . \ldots$

2.1 Photovoltaic System Technology ........................ 5

2.1.1 Photovoltaic Effect ........................ 5

2.1.2 Photovoltaic Systems ........................ 6

2.1.3 Silicon Module Production Process .................. 7

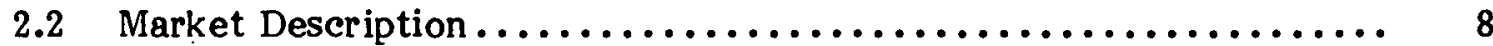

2.3 Photovoltaics Program Philosophy ..................... 12

2.4 Relationship of International Activities to

Photovoltaic Technology Evolution ................... 14

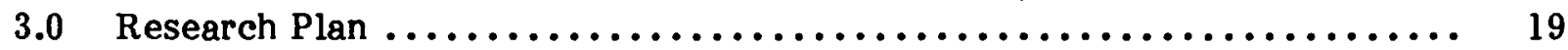

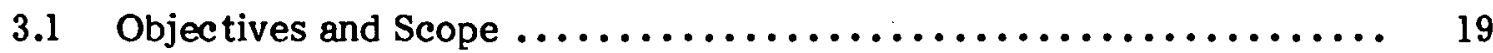

3.2 Methodology .................................. 19

3.2.1 Step 1: Task Preparation....................... 19

3.2.2 Step 2: Initial ISCWG Meeting .................. 21

3.2.3 Step 3: Agency Visits........................ 21

3.2.4 Step 4: Analytical Tasks ....................... 21

3.2.5 Step 5: Second ISCWG Meeting;

Review Research Results...................... 23

3.2.6 Step 6: Draft Plan .......................... 23

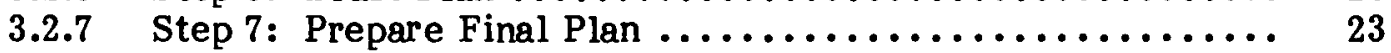

3.2.8 Step 8: Final Plan to Congress ..................... 23

3.3 Study Participants and Management Plan ................. 23

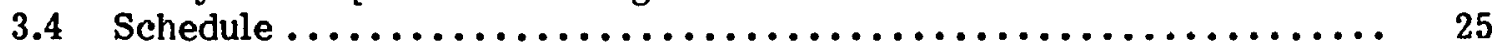

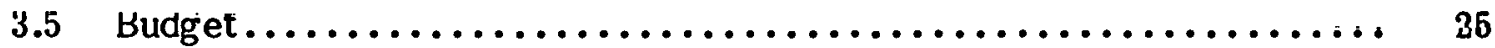

4.0 Objectives of the International Plan $\ldots \ldots \ldots \ldots \ldots \ldots \ldots \ldots \ldots \ldots \ldots \ldots$

4.1 Statement of Objective $\ldots \ldots \ldots \ldots \ldots \ldots \ldots \ldots \ldots \ldots \ldots \ldots \ldots \ldots$

4.2 Numerical Objectives for the

International Plan ............................ 28

$5.0 \quad$ Strategies and Tactics $\ldots \ldots \ldots \ldots \ldots \ldots \ldots \ldots \ldots \ldots \ldots \ldots \ldots \ldots \ldots \ldots \ldots$

5.1 Photovoltaic System Demonstrations................... 31

5.2 Systems Development............................ 32

5.3 Information Gathering: Supplier Assistance................ 32

5.4 Information Dissemination: Market Assistance.............. 32

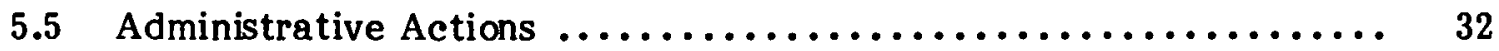

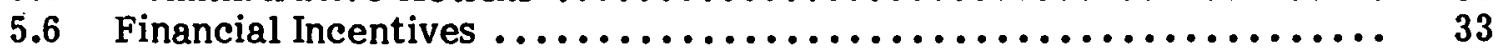

5.7 Monitoring, Assessment, and Coordination ............... 33

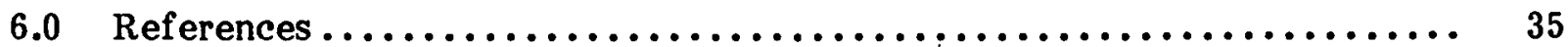


SERI* 


\section{LIST OF PIGURES}

Figure

2-1 Research, Development, and Demonstration Process

for Components and Systems................ 13

2-2 A Technology Evolution Scenario .............. 16

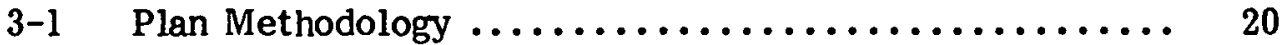

\section{LIST OF TABLES}

Table

2-1 Initial (1977) Break-Even Prices and Annual Market Potentials for Four Market Scenarios

2-2 Estimated Foreign Module Sales Projections by Market Segment in MWp (Annual).

2-3 Key Milestones in the Photovoltaic RD\&D

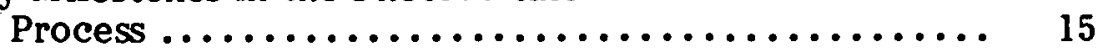

$3-1 \quad$ Schedule $\ldots \ldots \ldots \ldots \ldots \ldots \ldots \ldots \ldots \ldots \ldots \ldots \ldots \ldots \ldots, 25$

$3-2 \quad$ SERI Budget Summary $\ldots \ldots \ldots \ldots \ldots \ldots \ldots \ldots \ldots \ldots . \ldots \ldots$

3-3 JPL and MIT Budget Summary $\ldots \ldots \ldots \ldots \ldots \ldots \ldots \ldots$ 


\section{SERI䊩}




\section{SECTION 1.0}

\section{INTRODUCTION}

The Solar Photovoltaic Energy Research, Development, and Demonstration Act of 1978 (P.L. 95-590) was signed into law on November 4, 1978. Two of the key findings of the Act (Section 2) are that (1) "photovoltaic energy systems are economically competitive with conventional energy resources for a wide variety of applications in many foreign nations at the present time, and will find additional applications with continued cost reduction" and (2) "the early development and export of solar photovoltaic energy systems, consistent with the established preeminence of the United States in the field of high technology products, can make a valuable contribution to the well-being of the people of other nations and to this Nation's balance-of-trade."

Based on these findings, Congress called for actions to stimulate international participation and cooperation in photovoltaics. In particular, Section $11(a)$ of the Act states,

Within one year after the date of the enactment of this Act, the Secretary, in consultation with the Secretary of State, the Administrator of the Agency for International Development, the Director of ACTION, the Director of the Export/Import Bank, and other appropriate Federal officials, shall submit to the House Committee on Science and Technology and the Senate Committee on Energy and Natural Resources a plan for demonstrating applications of solar photovoltaic energy systems and facilitating their widespread use in other nations, especially those with agreements for scientific cooperation with the United States. (b) The Secretary is authorized to encourage, to the maximum extent practicable, international participation and cooperation in the development and maintenance of programs established under this plan. The Secretary, in consultation and cooperation with the Federal officials specified in subsection (a) shall insure to the maximum extent possible that the plan submitted under subsection (a) and any other international activities under this section are consistent with and reflective of any similar activities or requirements under any other Federal statute, specifically including any of the several programs under other agencies and Departments involving United States international cooperation and assistance in nonnuclear energy technology, and will not duplicate activities under such programs. The plan required in subsection (a) shall specifically identify all such programs and statutes and describe how the activities under this section will be consistent with such programs, will be coordinated with them, and will avoid duplication of activities under such programs. [1, Section 11(a)]

In addition to this legislation, a number of studies and statements of photovoltaic experts highlight the importance of international markets in the commercial development of photovoltaics. For example, each of the market scenarios developed in the SERI Photovoltaic Venture Analysis contained a large international market sector $[2, \mathrm{pp} .23-36]$. This international market always leads to near-term and intermediateterm photovoltaic sales that are larger than domestic markets. Only in the long-term, when U.S. grid-connected markets are penetrated, do the U.S. sales dominate foreign sales in any market scenario. A Department of Energy (DOE) report recently submitted to Congress concluded, "By 1986 the foreign market will be almost four times the size of the U.S. domestic market for present applications. Present sales volumes are about 
equal." The report continued, "The projected growth of the foreign market by 1986 is largely attributed to the potential water pumping and village power applications in developing countries" [3, p. 21].

The current photovoltaic industry also stresses the importance of international markets and the need for U.S. government assistance in penetrating those markets. Numerous representatives of the industry expressed this belief at hearings on the Solar Photovoltaic Energy Research, Development, and Demonstration Act of 1978. A group of industry representatives in a recent workshop were asked to choose 30 key events in the future commercial development of photovoltaics. Before choosing the events, the workshop participants all agreed that one of the basic assumptions should be: "The non-U.S. photovoltaic market is larger than the U.S. market and is growing initially faster" $[2$, p. 84].

These events and perceptions emphasize the need for a coherent plan for U.S. government assistance in the development of international photovoltaic markets. The purpose of the plan is to fulfill the requirements of P.L. 95-590 and to provide a framework for accelerated worldwide use of photovoltaic systems and for U.S. penetration of international photovoltaic markets. The plan both affects and is affected by a number of U.S. government and private international organizations. These organizations are the key to the plan's success. Therefore, the preparation of the plan will be responsive to the perceptions and constraints of the organizations.

This working paper represents the first step in deriving an international plan that actively seeks the participation of interested organizations. The working paper is designed to introduce basic knowledge of photovoltaic technology, the planning process, and possible strategies that might be pursued. The paper also contains the schedule for completing the plan by the November 1979 Congressional deadline.

A description of photovoltaic technology and its potential markets is presented in Section 2.0. The current DOE photovoltaic program plan is outlined. The section concludes with a discussion of how the international plan will be related to the domestic program. The coordination of domestic research, development and commercialization activities, and international market stimulation are important for the success of the program. Considerations for this balance will be a key element in the preparation of the international plan.

Section 3.0 describes the schedule and tasks to be carried out in completing the plan. The major activities deal with collection of information and expert opinion from involved government agencies, the photovoltaic industry, international finance institutions, foreign governments, and nongovernmental organizations.

Section 4.0 discusses the objectives of the international plan. In the next three to five years, the plan's major objective should be to maintain, stabilize, and foster the expansion of the U.S. photovoltaic industry and to facilitate international market development. In later years the focus should be on contributing to the economic, political, and social advance ment of developing nations.

Section 5.0 lists and describes alternative strategies available to the U.S. government. Information dissemination to foreign consumers, governments, and international finance institutions is one strategy that will be addressed. Technology development activities aimed at systems that would be used in international markets could be another possible strategy. The plan also could include market information-gathering activities for use by 
the U.S. photovoltaic industry. Photovoltaic demonstration projects related to international markets represent an important strategy that could be included. Other strategies are financial incentives for international photovoltaic sales and administrative actions intended to promote foreign market development. Ongoing coordination and cooperation of U.S. government agencies involved in international photovoltaic programs and feedback to the government on the success of its activities comprise the final strategy. 
SER' 


\section{SECTION 2.0}

\section{BACKGROUND}

This section provides background information relevant to the preparation of the international market development plan. The status of photovoltaic systems and array technologies is summarized. Current and potential markets for photovoltaic systems are described. Next, the philosophy and organization of the DOE Photovoltaics Program is reviewed. Finally, the relationship of the photovoltaics program activities to possible international activities is discussed.

\subsection{PHOTOVOLTAIC SYSTEM TECHNOLOGY}

Solar photovoltaic energy conversion is one of the half dozen technologies that comprise the solar option.* Photovoltaic technology exhibits both strong attributes and difficult implementation problems.

Like all solar technologies, the source of photovoltaics is inexhaustible. Photovoltaic cells provide direct conversion of solar radiation to energy in the most refined of all forms, electrical power. Economies of scale do not dominate photovoltaics as they do some of the other solar technologies. Applications encompassing all size ranges may be considered. The solar cell is also a fundamentally simple structure that uses available raw materials, has a strong existing industrial manufacturing base, and requires little special knowledge or skills to use.

The basic problem with photovoltaic conversion, as with most solar technologies, is cost. At circa 1977 prices for solar cells of $\$ 11$ per peak watt (Wp) of output, the cost of photovoltaic energy would be $\$ 1-2 / \mathrm{kWh}-20$ times the competitive range for utilitygenerated power in the United States. This cost is competitive for some applicationsspace satellites, communications equipment, corrosion protection for bridges and pipelines, aids to navigation, and other applications-that do not have ready access to the utility power grid. However, the total nongovernmental de mand for solar cells at $\$ 11 / \mathrm{Wp}$ is well below $1 \mathrm{MW}$ of peak capacity per year and does not yet provide the base for the multi-MW annual production levels that will be required to reach DOE's price goals for solur cells modules; $\$ 2 / \mathrm{Wp}$ by 1982 and $\$ 0.50 / \mathrm{Wp}$ by 1986 (1975 dollars).

\subsubsection{Photovoltaic Effeet}

A photovoltaic device converts light energy (photons) into electrical energy (a voltage). This phenomenon is known as the "photovoltaic effect" and involves the excitation of electrons by absorption of light, thus permitting their movement through a "semiconduc tor" material.

Materials are referred to as "semiconductors" because they conduct electricity only if they contain appreciable numbers of electrons which can be excited across a band of energy states (a band gap) into the conduction band. Conductors, such as copper, have no

\footnotetext{
* Others are solar thermal, solar thermal electric, wind, ocean thermal, and bioconversion.
} 
band gap. When semiconductors are specially treated or doped, they are capable of converting incident energy (light) into electrical energy. Therefore, solar cells are special types of semiconductors.

In a photovoltaic cell the conversion of light to electricity is accomplished by electrons that absorb energy from photons and jump to higher energy states. The electronic energy transition is followed by a separation of electrons and vacant energy states or "holes" producing a distribution of charge that causes a difference in voltage between the front (sunlight side) and back of the solar cell on the order of half a volt.

A silicon solar cell is typically a thin $(1 / 4 \mathrm{~mm})$ wafer, approximately $5-10 \mathrm{~cm}$ in diameter, consisting of two layers. Materials other than silicon can be used for photovoltaic cells and are the subject of $R \& D$ efforts at the present time. Among these materials are gallium arsenide (GaAs), cadmium sulfide (CdS), copper sulfide $\left(\mathrm{Cu}_{2} \mathrm{~S}\right)$, and indium antimonide (InSb). Whatever the material, the essential features of a photovoltaic cell are the same.

\subsubsection{Photovoltaic Systems}

Solar cells are only one part of complete solar photovoltaic power conversion systems. A photovoltaic system contains array structures to support the modules, circuitry to control and modify output in various ways and a means of storing energy, if required.

The cost of the array structures that support the modules are estimated to be a significant portion of photovoltaic system cost. Ancillary circuitry also may be costly; the direct current (DC) produced by solar cells in some applications must be changed to alternating current (AC) used by most electrical loads and utility systems. For many applications, electrical storage is needed to provide electrical power when the array is not producing power or to supplement the array output during transient loading. In addition, a means of regulating the flow of power between the solar array, energy storage, and load, are often required. The exact design and balance of system costs depend on the application in which the system will be used. Also, the word "system" may be defined to include the application; e.g., a photovoltaic driven pump.

The flat-plate collector, or array, is composed of a number of panels which, in turn, contain the photovoltaic cells. The cells and panels are connected in series and are parallel to provide the voltage and current output ratings required by the individual application. 'The cells in the panels are covered with clear plastic or glass and are sealed against environmental elements. The output per unit area is dependent on the "packing density" and other efficiency and degradation factors.

Solar arrays are expected to be highly reliable and nearly maintenance free. The principal cause of failure in photovoltaic arrays is the corrosion of electrical contacts after moisture penetrates the array through lamination separations and other "packaging" failures. Little data defining the life of arrays are available. However, it is believed that the packaging problem can be overcome as the technology matures, and array lives of 20 years and more are probable.

Currently, commercial systems that service relatively small operating power requirements employ lead-acid batteries as the storage medium. The characteristics of batteries used with photovoltaic systems vary among applications. For photovoltaic systems operating in an augmentation mode, shallow discharge cycles may compensate 
from passing clouds and other brief interruptions. However, long lives with deep discharge cycles will be required for solar energy systems to provide continuous power supplies during long, no-sun periods. High discharge rates may also be required to provide instantaneous power when induction motors are on line.

Power conditioning units contain two components: a power inverter and a shunt regulator. The purpose of the inverter is to transform the $\mathrm{DC}$ electricity received from the collector or electric storage device into AC which may be needed for some applications. Several types of inverters exist which are appropriate for use with photovoltaic generators. In many applications, a photovoltaic system is replacing another DC power source, such as primary batteries or thermal electric generators. For these systems, no inverter is needed. Shunt regulators are used to prevent overcharging of the batteries.

\subsubsection{Silicon Module Prodretion Process}

While there are many types of materials that can function as photovoltaic cells, there is also a multitude of ways in which silicon photovoltaic cells can be fabricated and manufactured into photovoltaic modules. These technologies generally are classified as ingot, noningot, or concentrator technologies.

The present production process for silicon solar cells (ingot) begins with quartz, a relatively pure form of $\mathrm{SiO}_{2}$. This is reduced to metallurgical-grade silicon. The next step is to refine the silicon to semiconductor-grade. The purity, cost, and production volume of this material is determined by the requirements of the semiconductor industry, since that industry uses most of the high-purity silicon produced. The purity and quantity requirements of silicon solar cells are sufficiently different that a growing demand for solar power devices would be likely to result in production of a lower purity, lower cost, solar-grade polycrystalline silicon.

Next, the semiconductor-grade, or polycrystalline silicon, is recrystallized to form single-crystal silicon by a method called the Czochralski process, a technique commonly used in the semiconductor industry. The first step in this process is to melt the semiconductor-grade silicon and dope it with very small quantities of other elements (boron, phosphorous) to make it n-type or p-type. A small silicon seed crystal is, then, dipped in a pool of the molten semiconductor-grade silicon to initiate crystal growth and withdrawn slowly, pulling with it a large, growing, cylindrical single crystal of silicon (a boule). Depending on the speed of pulling and the rate of cooling, boules of $7-10 \mathrm{~cm}$ in diameter are produced. Larger diameters have advantages in production efficiency, and research into larger boules has yielded diameters as large as $30 \mathrm{~cm}$.

The Czochralski crystallization process is followed by a sawing step to cut the cylindrical boule into flat wafers. The present sawing technique might be improved by reducing the width of the saw blades and the thickness of the wafers. Silicon is wasted in sawdust and in unnecessarily thick wafers.

Then, the wafers are doped with an impurity that is the opposite of the one used in the crystallization process. These impurities diffuse in a short distance into the surface of the cell as the wafers are heated in an oven. Most photovoltaic cells are made of $p$-type wafers with a thin $n$-type layer on the sunlit side.

Metal contacts are applied to the front and back of the wafers, and antireflective coatings are applien to the front of the cells to reduce the amount of solar energy which 
is lost as reflection from the front surface of the cell. The finished solar cells are wired in series, in parallel, and encapsulated in glass or plastic for weatherproofing to form an array.

Analyses indicate that, with improvements in production techniques, ingot technology has a high probability of leading to modules produced at $\$ 2.00 / \mathrm{Wp}$ (1975) in the near future. Further reductions in the cost of ingot-produced arrays are also possible.

The second process, noningot technology, involves the creation of a thin crystalline silicon sheet as opposed to an ingot. This is accomplished by pulling a continuous ribbon or web of material from a replenished melt. This process uses silicon material (similiar to polycrystalline silicon used for ingot solar cells) much more conservatively by avoiding sawing losses since slicing is no longer required. The packing density also improves since rectangular cells, rather than round cells, result. It is possible that noningot arrays could be produced for $\$ 0.50 / \mathrm{Wp}$ or less in the 1986 time frame.

'I'here are no obvious barriers to the production of photovoltaic concentrating systems, which today use single-crystal silicon cells. Photovoltaic concentrators use special mirrors or lenses to focus incident light on the photovoltaic cell. Some concentrating arrays are designed to track the sun's path to maximize the energy collected. Concentrators require fewer solar cells and, therefore, the total cost of photovoltaic cells required for a given area of collector is low (a direct inverse function of concentration ratio). The technologies required to manufacture concentrating Fresnel lenses and mirrors are well known, as are the production processes of tracking systems. Production and design improvements that could reduce concentrator costs are being examined now. $\mathrm{R} \& \mathrm{D}$ efforts are also being directed at high-efficiency cells for use in concentrators (i.e., gallium arsenide).

\subsection{MARKET DESCRIPTION}

Reductions in photovoltaic system prices that menrred in the 19708 have opcnod up a number of terrestrial markets for photovoltaics. Prior to 1970, photovoltaic module sales were used almost exclusively in space systems. These space cell modules initially cost over $\$ 200 / \mathrm{Wp}$. Today, with photovoltaic module prires at approximately $\$ 11 / \mathrm{Wp}$, the major terrestrial markets for photovoltaics are in communications and cathodic protection systems. In both of these markets, sales are being made for systems that are operating in remote locations with small power requirements. Utility power typically is not available, or the cost of utility line extension is prohibitive. Batteries, thermal electric generators, and diesel generators are power sources for which photovoltaio systems currently are substituted. Both batteries and small-scale generators have high maintenance costs; generators typically have poor reliability characteristics and need fuel, making them expensive to use in a remote setting.

A small quantity of today's sales are made in consumer and recreation markets (i.e., battery chargers for sailboats and watches) and for remote water pumping systems located in foreign countries. Purchases by the U.S. photovoltaic program continue to account for a significant portion of total photovoltaic sales.

Annual sales of photovoltaic modules by U.S. companies have yet to exceed $1 \mathrm{MWp} / \mathrm{yr}$. In 1976, two studies estimated worldwide sales at $400 \mathrm{kWp} / \mathrm{yr}[4,5]$. The 1977 sales estimates were $750 \mathrm{kWp}$, with shipments of approximately $500 \mathrm{kWp}$ [6, p. III-3]. One study projected 1978 sales of approximately one $\mathrm{MWp} / \mathrm{yr}$, with shipment of 700 to 
$800 \mathrm{kWp}$ [6, p III-1]. Approximately half of the 1978 sales are estimated to have been in foreign markets [3, pp. 2-3].

Several studies have attempted to describe the future development of these current markets, as well as new photovoltaic markets $[4,5,7]$. Most of these studies were summarized and updated in the SERI report, Photovoltaic Venture Analysis [2, pp. 23-36; D-1 - D-130]. Available market information was used in the Venture Analysis to develop four market scenarios that characterize potential markets for photovoltaics. These scenarios are shown in Table 2-1. Completed photovoltaic market research, while sufficient to provide a rudimentary indication of how photovoltaic markets might develop, does not allow the construction of any single-market scenario in which a high level of confidence can be placed.

In Table 2-1, break-even prices and annual potential market sizes are shown for each market sector. Break-even price and annual potential market size are important parameters in characterizing how any market will develop. A higher break-even price indicates higher costs of competitive power systems. Photovoltaics, therefore, become a more effective competitor in the larger market scenarios. Market potential is the upper boundary on annual potential sales and reflects the size of the market for which photovoltaics could compete. Actual sales may only be a small percentage of the potential market.

Several observations can be made from Table 2-1. Current markets, such as U.S. and foreign communications and cathodic protection, represent only modest future markets, even under the most optimistic of the market scenarios. The potential size of these markets ranges from approximately 5-25 MWp/yr. These markets, however, can be penetrated at relatively high photovoltaic system prices, such as those typical of today's systems. Under all of the scenarios, U.S. and foreign markets are approximately equal in size for current applications.

Table 2-1 contains several potential intermediate markets. Intermediate refers to a market in which photovoltaics might be used, should substantial photovoltaic system price reductions be achieved. The $\$ 3-10 / \mathrm{Wp}$ system price needed for photovoltaics to compete in intermediate markets is still well above the system prices at which photovoltaics could compete with utility-generated power in the United States (markets 13 and 14 in Table 2-1).

Four potential U.S. intermediate markets are shown: outdoor lighting, Department of Defense (DOD) applications, other U.S. government applications, and consumer applications. These markets have a total potential size ranging from $10 \mathrm{MWp} / \mathrm{yr}$ to nearly $400 \mathrm{MWp} / \mathrm{yr}$ in the four-market scenarios. The major components of the very large market scenario are lighting and DOD applications, both of which are highly speculative markets.

Table 2-1 also shows three major foreign intermediate markets. These are low-lift and medium-lift pumping applications, and general power systems for remote villages. The total size estimates for these markets range from $16 \mathrm{MWp} / \mathrm{yr}$ to $305 \mathrm{MWp} / \mathrm{yr}$. Should the U.S. lighting market prove not to be very promising, as has been suggested by several experts, international markets have the greatest potential for photovoltaic sales in the intermediate photovoltaic system price range.

The recently completed report on the export potential for photovoltaic systems arrived at similar conclusions [2]. Table 2-2 presents the foreign market sales forecasts made in 
Table 2-1. INITIAL (1977) BREAK-EVEN PRICES AND ANNUAL MARKET POTENTIAIS FOR FOUR MARKET SCENARIOS ${ }^{a}$

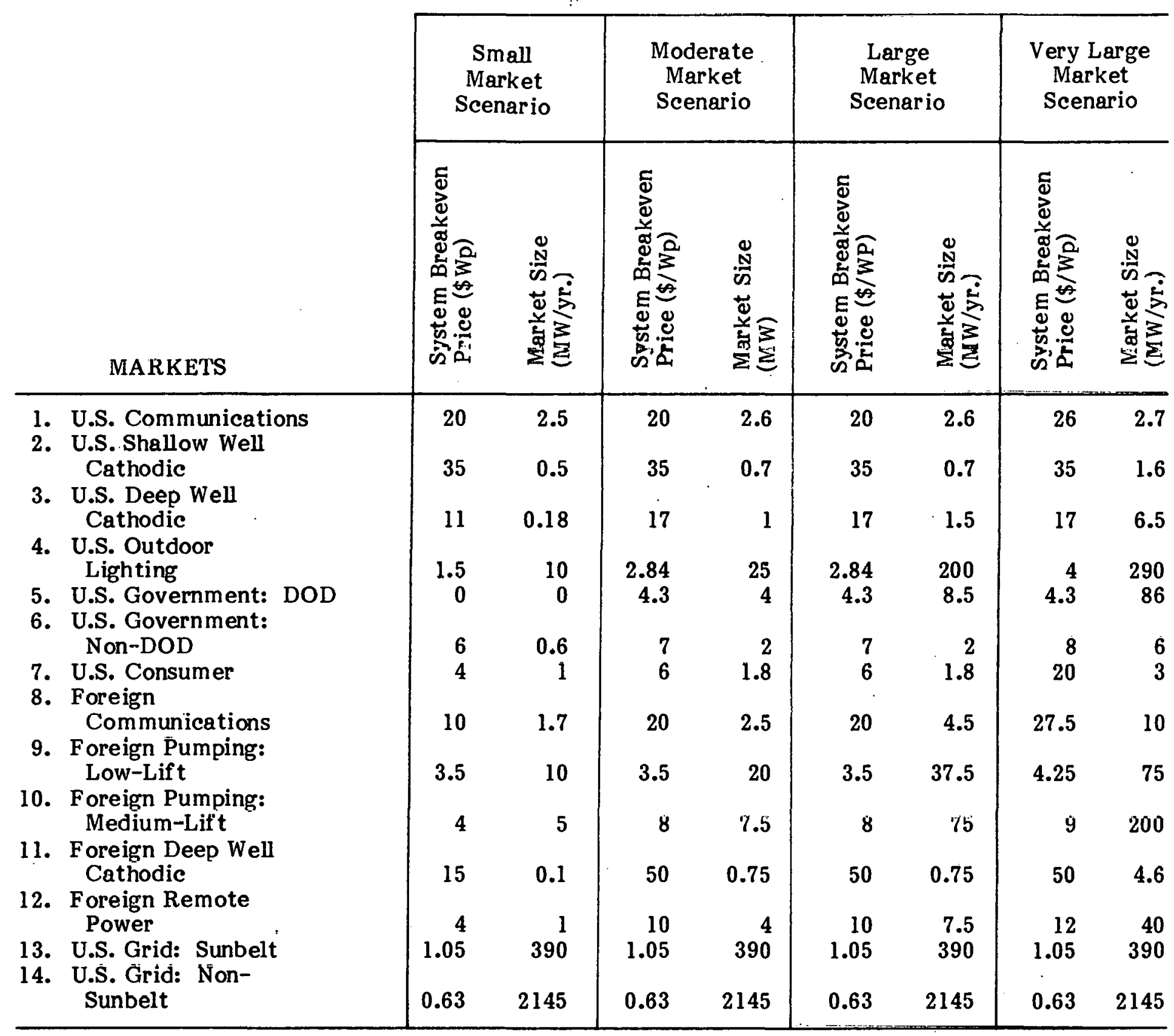

${ }^{a}[2$, p. 51$]$. 
Table 2-2. ESTIMATED FOREIGN MODULE SALES PROJRCTIONS BY MARKET SEGMENT IN MWP (ANNUAL) ${ }^{\mathrm{Q}}$

\begin{tabular}{|c|c|c|c|c|c|c|c|c|c|c|c|c|c|}
\hline Market Segmients & 1978 & & 1982 & & & 1986 & & & 1990 & & & 000 & \\
\hline & & $\mathrm{L}$ & $\mathbf{M}$ & $H$ & L & $\mathbf{M}$ & H & $\mathrm{L}$ & $\mathbf{M}$ & $\mathrm{H}$ & L & M & $H$ \\
\hline Corrosion Protection & 0.008 & 1 & $\underline{1.5}$ & 1.5 & 3.2 & $\underline{4.5}$ & 4.9 & 6 & $\underline{8.5}$ & 11 & 11 & 17 & 25 \\
\hline Coinmunicetions & 0.4 & 2 & 2.8 & 3.2 & 5.2 & $\underline{7.5}$ & 9.5 & 8 & $\underline{11}$ & 15 & 11 & 12 & 24 \\
\hline $\begin{array}{l}\text { Marking and Warning } \\
\text { Devices }\end{array}$ & 0.04 & 0.05 & $\underline{0.3}$ & 0.4 & 0.52 & $\underline{1.2}$ & 2.2 & 1.6 & $\underline{2.8}$ & 4.5 & 3.5 & $\underline{7.5}$ & 10 \\
\hline Water Pumping & 0.05 & 1.2 & $\underline{5.2}$ & 5.7 & 3.7 & $\underline{29}$ & 88 & 9 & $\underline{78}$ & 250 & 70 & 470 & 900 \\
\hline $\begin{array}{l}\text { General Village } \\
\text { Power Sources }\end{array}$ & 0.006 & 0.3 & $\underline{0.6}$ & 1.5 & 0.9 & $\underline{10}$ & 24 & 3 & $\underline{25}$ & 100 & 10 & 100 & 400 \\
\hline Consumer Products & 0.009 & 0.1 & $\underline{0.1}$ & 0.1 & 0.1 & 1 & 1.3 & 2.4 & $\underline{3} . \underline{5}$ & 4.4 & 8 & 9.5 & 14 \\
\hline TO'IAL & 0.513 & 4.65 & 10.5 & 12.4 & 14 & $\underline{53}$ & 130 & 30 & $\underline{129}$ & 380 & 106 & 621 & 1,373 \\
\hline
\end{tabular}

${ }^{8}[3$, pp. $2-6]$. 
this study. Forecasts contained in this report indicate that foreign sales of communication and cathodic protection systems have the potential to grow more rapidly than U.S. sales in these markets during the early 1980s. The United States and foreign sales for current markets, however, are projected in the report to remain approximately equal until 1985 due to slower penetration in foreign markets. Foreign intermediate markets, such as water pumping and village power, are projected to be the dominant photovoltaic markets in the mid-1980s. As indicated in the Venture Analysis, there exists a high degree of uncertainty in these foreign inter mediate markets.

Existing markets have some potential for growth in both the United States and in foreign countries. The growth potential in these markets is limited and probably not sufficient to stimulate the growth of a large photovoltiac industry. If moderate reductions in photovoltaic system prices (to the $\$ 3-10 \mathrm{Wp}$ range) are achieved, there are several potential markets in which photovoltaics could compete. The characteristics of these inter rnediate markets and the requirements for market success are poorly understood. Intermediate markets in the United States are less likely to develop than intermediate foreign markets. One reason for this speculation is the greater technical uncertainty associated with U.S. lighting and DOD markcto, the two significunl U.S. Intermediate markets. Another reason is that foreign markets, particularly those in developing countries, will be willing to pay higher prices for photovoltaic systems because of the sparse development of their uitility power systems and higher power costs.

The foreign water pumping and village power markets are considered the markets with the greatest future opportunity for photovoltaic sales. Pumping applications are particularly promising because of the coincidence of energy needs and solar insolation. It is likely that the primary customers in the village power and water pumping markets will be foreign governments, international developers, and finaneing agenoies. Much work needs to be done to understand and develop these markets before the market potential and sales forecasts cited above can be translated into significant sales.

\subsection{PHOTOVOLTAICS PROGRAM PHIILOSOPHY}

While the technical feasibility of photovoltaic energy systems is a demonstrated fact, the current costs of systems have confined their use to small-scale, remote applications. To achieve significant fuel displacement in the United States,* photovoltaic systems must be capable of producing electricity "cost competitive with utility-generated electricty from conventional sources." The objective of the DOE Photovoltaics Program is to reduce system costs to a competitive level in major U.S. energy markets through "extensive research, development, and demonstration, and limited product support." The program also will resolve the technical, institutional, legal, environmental, and social issues involved in fostering widespread adoption of photovoltaic energy systems.

The Solar Photovoltaic Energy RD\&D Act of 1978 authorized a 10 -year, $\$ 1.5$ billion federal program to achieve this and other related objectives. Fig. 2-1 describes the DOE Photovoltaics Program in terms of the RD\&D process for components and systems. This figure defines major program milestones and the steps between initial concepts and their possible widespread commercial use. The top line shows the steps followed in the

*The recently completed Solar Energy Domestic Policy Review estimates 1.0 Quad of primary fuel for the "maximum practical case" and 0.1 Quad for the "\$25/bbl base case." 


\section{COLLECTOR AND BALANCE-OF-SYSTEM COMPONENTS}

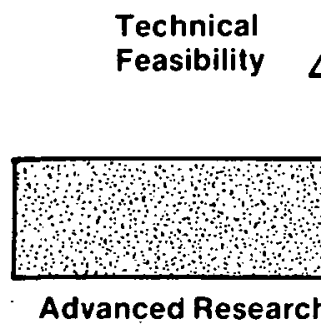

and Development

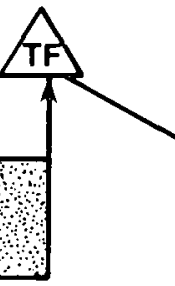

?t?

E

\section{Applications/Systems}

Definition/Development

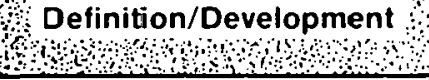

System Engineering and Standards
Technology

Development

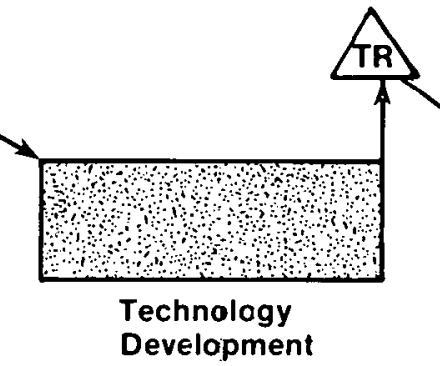

AR Technology Readiness

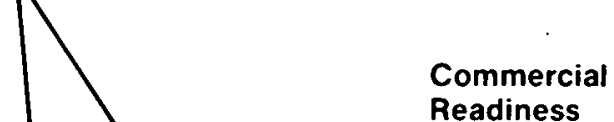

Commercial
Readiness

A.
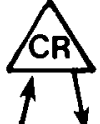

- Industrialization - Demonstrations

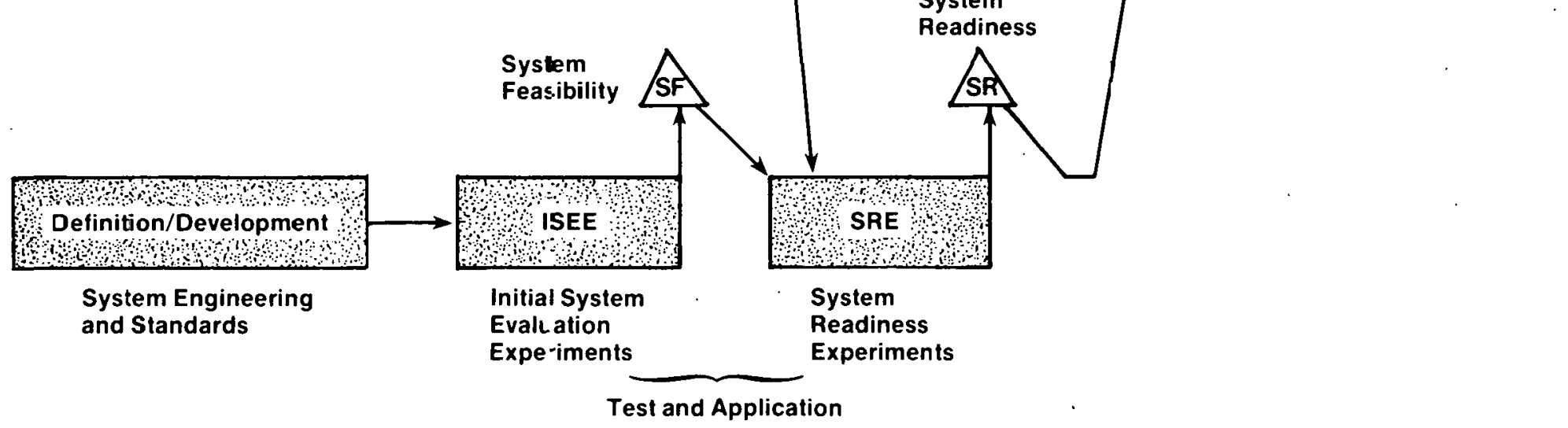

Figure 2-1. Research, Development: and Demonstration Process for Components and Systems 
development of low-cost components for photovoltaic systems. The transition between each major program activity is identified by the milestones indicated. Each milestone is described in Table 2-3. At each step, a winnowing process occurs where the most promising components or techniques are carried to the next step.

While potential low-cost components are essential to program success, they still must be incorporated into systems that meet the requirements of specific applications. The "Applications/Systems" line begins with analysis of user requirements, leading to definition and development of several alternative systems and their requirements on components. Systems are initially those tested in a laboratory environment. Then, the most attractive candidate systems are tested in the end user's environment to establish system feasibility (Initial System Evaluation Experiments, ISEE) and, finally, system readiness. Systems successfully emerging from System Readiness Experiments (SRE) should meet user requirements and have the potential of being produced commercially at the price garl establisher for that application. At tho Commcrcialization stage, photovoltaic systems are cost competitive on a life-cycle cost basis and are ready, then, for widespread commercialization. Demonstration of commercial readiness then could be shown through Commercial Readiness Demonstration Projects (CRDP). Incentives to help market development and reduce costs through economies of scale in production could also be implemented during this stage.

Key elements of the DOE Photovoltaics Program strategy include:

- Substantial reductions in the price of components and subsystems via:

- aggressive advanced research and development to bring advanced concepts to the point of technical feasibility; and

- intensive technology development to identify, develop, and suitably demon= strate cost-effective designs and production processes for components for which technical feasibility has been proven, thereby establishing their technology readiness.

- Definition, development, design, and testing of complete phntovoltaic systems in real-world applications to demonstrate, first, that such systems are feasible and, second, that they are ready for commercialization.

- Development of a substantial body of experience, confidence, and expertise within the private sector on the part of both users and suppliers of photovoltaic systems.

- Careful study and implementation of commercialization strategies that will encourage market penetration and stimulate emplacement of appropriate production capacity as photovoltaic technologies approach commercial readiness.

\subsection{REI ATIONSHIP OF INTERNATIONAL ACTIVITIES TO PHOTOVOLTAIC TECHNOLOGY EVOLUTION}

International markets could potentially fill the intermediate market "gap" between remote and grid-connected applications for photovoltaic systems in the United States. To help realize this potential, an international photovoltaics plan should account for anticipated changes in photovoltaic technology and markets. The plan should also account for activities already planned in the DOE domestic program.

Fig. 2-2 describes a scenario for the next decade that indicates the relationship of the evolving technology to the evolving market. Program decisions are aimed at guiding and 
Table 2-3. KEY MILESTONES IN THE PHOTOVOLTAIC RD\&D PROCESS

\begin{tabular}{|c|c|}
\hline Milestones & Requirements \\
\hline Technical Feasibility (TF) & $\begin{array}{l}\text { - Stable, reproducible performance } \\
\text { characteristics } \\
\text { - Laboratory-scale process yields products } \\
\text { with consistent performance } \\
\text { characteristics } \\
\text { - Mass production is feasible and likely } \\
\text { to produce an economically viable } \\
\text { product after suitable technology } \\
\text { development }\end{array}$ \\
\hline Technology Readiness (TR) & $\begin{array}{l}\text { - Appropriate subscale demonstration of } \\
\text { steps in production process } \\
\text { - Full-scale production process (i.e., in } \\
\text { sufficient quantity) expected to yield } \\
\text { product at or below price goal } \\
\text { - Representative products available for } \\
\text { intensive per for mance and reliability } \\
\text { analysis }\end{array}$ \\
\hline System Feasibility (SF) & $\begin{array}{l}\text { - System for a given application is } \\
\text { carried through detailed design, } \\
\text { installation, and successful operation } \\
\text { in user's environment } \\
\text { - Instrumented for detailed per for mance } \\
\text { evaluation }\end{array}$ \\
\hline System Readiness (SR) & $\begin{array}{l}\text { - System, using technology-ready } \\
\text { components or representatives thereof, } \\
\text { is designed, installed, and success- } \\
\text { fully operated } \\
\text { User environment, design, installation, } \\
\text { and operation representative of real } \\
\text { world } \\
\text { - System capable of being profitably } \\
\text { marketed at stated price goal }\end{array}$ \\
\hline Commercial Readiness (CR) & $\begin{array}{l}\text { - System can be purchased within stated } \\
\text { price range }\end{array}$ \\
\hline
\end{tabular}




\section{\begin{tabular}{|l|l|l|l|l|l|l|l|l|l|}
\hline 79 & 80 & 81 & 82 & 83 & 84 & 85 & 86 & 87 & 88
\end{tabular}}

| Phase 1

Phase 2
Phase 3

\section{Industry and \\ Technology \\ Evolution}

\section{Market \\ Evolution}

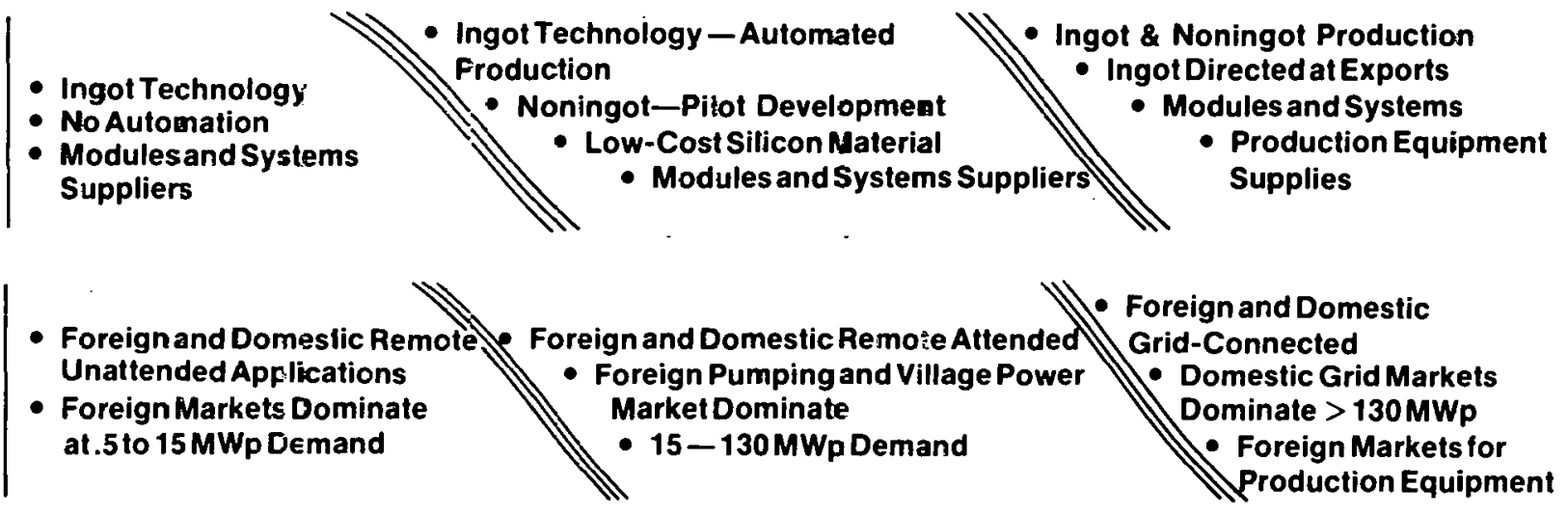

$$
\$ 25-10 / \mathrm{Wp}
$$$$
\$ 13-6 / W_{p}
$$$$
<\$ 1.60 / W p
$$

\section{System Application Experiments Evolution}

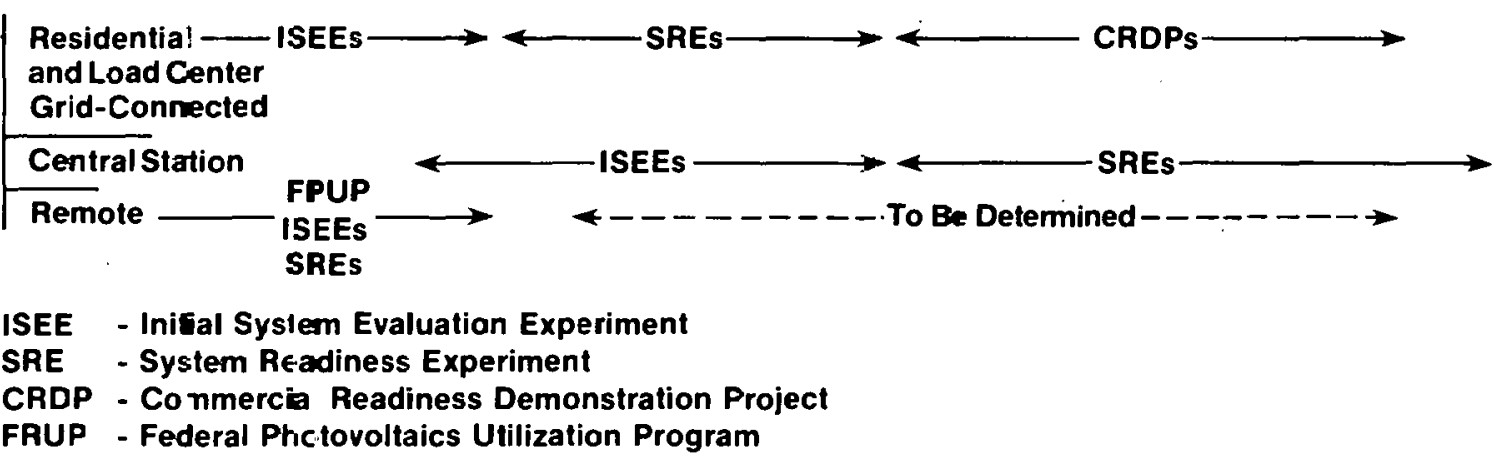

Figure 2-2. A Technology Evolution Scenario 
accelerating the technology through these phases with the objective of widespread commercial deployment in the United States and abroad in the late 1980s.

This scenario is characterized by three phases. The transition between each phase respresents a series of events that include technological change, cost reduction, and corresponding shifts in market emphasis. In general, industry investment decisions are required during the phase transitions and government program activities are aimed at facilitating this investment process.

Phase 1 can be characterized as the current situation. Photovoltaic modules are produced from silicon ingots in a nonautomated process. The industry is composed of a number of module suppliers (approximately 10), although several produce total photovoltaic systems for remote applications. Also emerging are entreprenuerial firms that buy modules from the industry to incorporate into remote systems (usually called systems houses). The market for current module production is for remote unattended systems such as microwave repeaters, navigational aids, and government system experiments. Of the total world demand, approximately half are for foreign applications. Current system prices are in the $\$ 25 / \mathrm{Wp}$ range. This pattern of remote foreign system sales and government purchase of test modules is expected to dominate until the early 1980s when the Phase 2 transition will occur.

The Phase 2 is characterized by the perception of a large foreign market of greater than $10 \mathrm{MWp} / \mathrm{yr}$ in pumping and village power applicatons (remote attended). This perception plus possible government policy actions (i.e., a directed procurement strategy) calls forth private industry investment in automated production facilities utilizing ingot technology. The for $m$ of the collectors produced may be flat-plate, concentrators, or both. With the movement to automation in a competitive industry and increased balance of system volumes, prices will drop to the $\$ 6-13 / W p$ range. These prices are still not sufficiently low to penetrate U.S. grid markets substantially, but they could be low enough to generate 15-130 MWp demand overseas.

In the Phase 3 transition of the mid-1980s, another technological shift is taking place. Noningot module technology, which was under pilot development in Phase 2, is now ready for scaled-up production. With the mass domestic markets now perceived to be within reach, with Phase 2 revenues providing a stable source of revenue and with a mix of government actions (possibly procurements) designed to stimulate investment, noningot production lines are constructed. Less than $\$ 1.60 / \mathrm{Wp}$ systems for domestic applications are envisioned.

Ingot technology production will not necessarily become obsolete in this process. Ingot cells, due to their high efficiency, would still be appropriate for low-cost concentrators. Also, ingot technology modules may be more appropriate for foreign applications, where reliability may be important and lower cost less important. Finally, ingot-production technology may be highly favorable for overseas production due to greater labor requirements and technology maturity. The export of ingot production equipment or turnkey factories by U.S. equipment suppliers is included in the later stages of Phase 3.

The final column in Fig. 2-2 depicts the currently envisioned phasing or system application experiments in the domestic photovoltaic program for residential and intermediate load center applications, central power station applications, and remote (nongridconnec ted) applications. 
SEPI 


\section{SECTION 3.0}

\section{RESEARCH PLAN}

\subsection{OBJECTIVES AND SCOPE}

The major objective of this research plan is to develop an international plan for demonstrating and facilitating the widespread use of photovoltaics in other nations. A secondary objective is to provide information and foster communication among various U.S. government agencies that are undertaking related international activities. The planning process also will involve current U.S. photovoltaic suppliers. Interactions between suppliers and various government agencies will lead to better understanding of the problems facing both groups.

Planning will begin with defining the objective to be accomplished. (Section 4.0 presents an initial discussion of the plan's objective.) Once the objective is identified, the plan will outline a set of strategies to achieve the objective. (Section 5.0 presents some preliminary strategies.) During the planning process, strategies will be refined further into tactics. Tactics represent specific actions that must be taken to implement a strategy. As required in the Solar Photovoltaic RD\&D Act, related programs being conducted by all U.S. government agencies will be identified and described. The roles that these agencies and programs could play in facilitating the development of international markets for photovoltaics will be addressed in the plan.

The plan, prepared as a result of this effort, will be a strategic and tactical plan. Agency actions or tactics will be addressed to the extent that time and practicality permit. No new market information will be generated for the plan. Existing market information and expert opinion will be synthesized. The plan will not be based on quantitative models or simulations; the most important planning issues cannot be addressed with such models. Although rigorous logical methods will be used as much as possible, model development will not be used as an aid to the planning process.

The plan will not be a forecast of future photovoltaic markets or the U.S. photovoltaic industry share of those markets. In the words of Peter Drucker, "We must start out with the premise that forecasting is not a respectable human activity and not worthwhile beyond the shortest of periods. Strategic planning is necessary precisely because we cannnot forecast" [8, p. 124]. The plan will attempt to gain a better understanding of the uncertainty of future events so that risk can be considered in government actions.

Finally, the plan will contain a mechanism to manage and provide decision makers with systematic feedback on the results of their decisions and government programs.

\subsection{METHODOLOGY}

The preparation of the plan consists of eight steps. Fig. 3-1 presents the steps and shows their relationships to one another. A discussion of each step follows.

\subsubsection{Step 1: Task Preparation}

The first step is to assemble a project team responsible for preparing the plan and an interagency review panel which will guide the plan's development. Preparation of this 

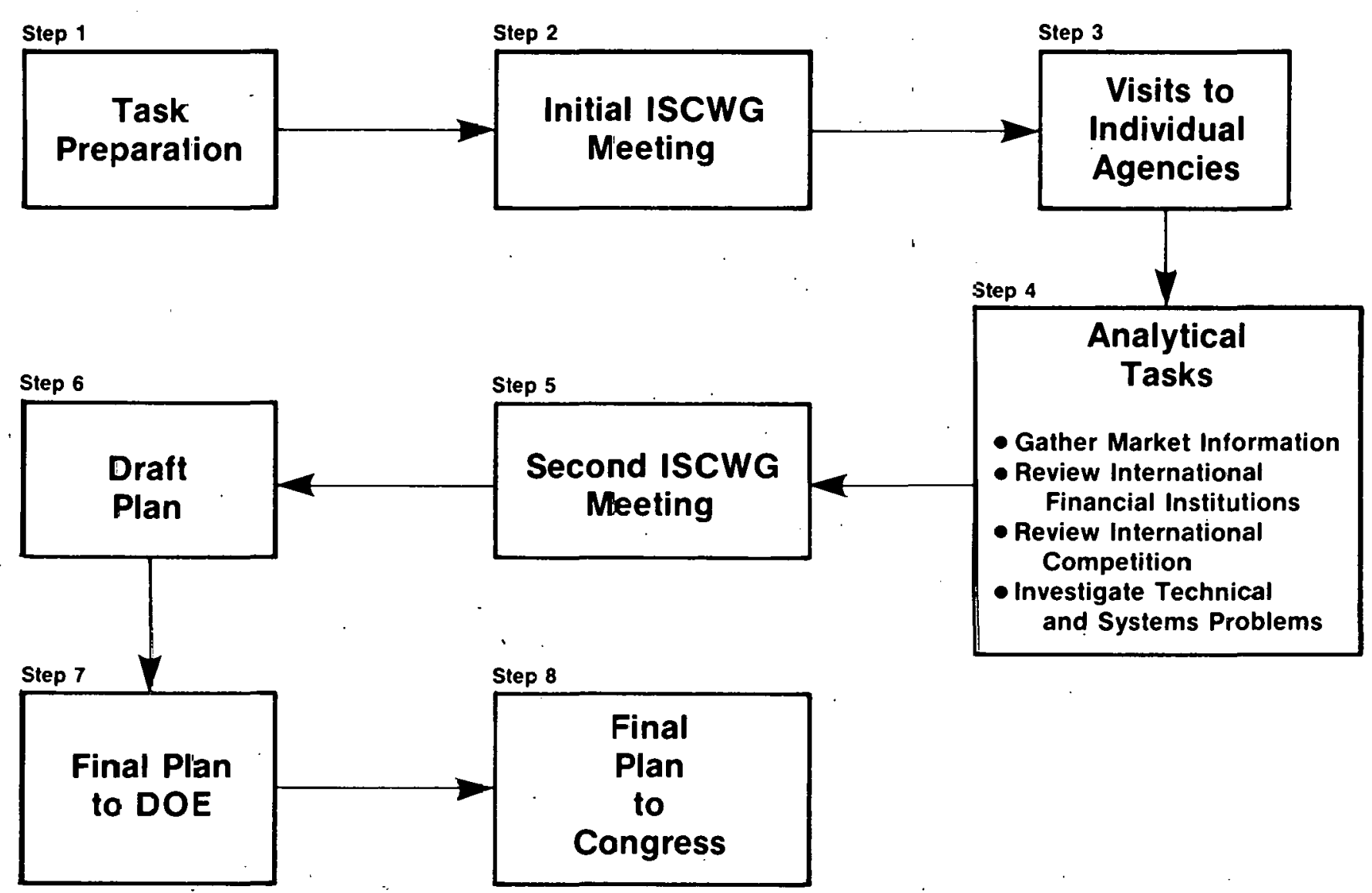

Figure 3-1. Plan Methodology 
working document, which defines the roles of these two groups and describes the planning process is part of this step.

SERI has the lead responsiblity for preparing the international plan. The staff of the DOE Photovoltaics Lead Center for technology development and applications at JPL will work jointly with SERI staff and will be responsible for several analyses to be used in preparing the plan. SERI and JPL will coordinate and manage the work of other groups and selected subcontractors. These activities are described below under Step 4.

Fortunately, most of the members of the interagency review panel already have been brought together under the International Solar Commercialization Working Group (ISCWG). With the addition of a representative of ACTION, the committee represents all agencies listed in the legislation.

\subsubsection{Step 2: Initial ISCWG Meeting}

Members of the ISCWG met for the first time on May 18, 1979. The purpose of this meeting was to review a preliminary draft of this working document on objectives and strategies and to present the schedule and work plan. The meeting also served as an initial forum for the working group to discuss their opinions on objectives, strategies, and tactics.

\subsubsection{Step 3: Agency Visits}

The legislation requires the compilation of all statutes and programs relevant to facilitating international photovoltaic market development. In addition, the plan will require individual agencies to carry out the tactics to implement the strategies of the plan. SERI, with support from JPL, will work with individual agencies to compile the required statutes, programs, and to propose policy actions that could be included in the plan. Visits will be made to individual agencies to gather information on agency operations and programs. Based on these meetings, SERI will prepare draft lists of possible actions that agencies might take to achieve plan objectives. These agency drafts will be used to gather ideas on all of the possible tactics the government might use to facilitate the use of photovoltaics internationally. Initial draf ts for informal agency comment will be completed by July 31, 1979. Final drafts will appear as part of the plan.

\subsubsection{Step 4: Analytical Tasks}

Much of the resources expended in the preparation of the international plan will be devoted to a series of analytical tasks designed to gather information needed to prepare an effective plan. The analytical tasks fall into four general categories: (1) gathering market information; (2) reviewing the activities of international financial institutions; (3) reviewing the strength of international competition; and (4) investigating technical and systems problems which might confront photovoltaic systems for use in selected applications. All of these tasks will have a strong policy focus. Their purpose is to identify programs and policy actions that could further the plan's objectives.

Market information will be gathered from numerous sources. As a starting point, available statistical information on current and potential markets will be reviewed by SERI staff. Most of this information is summarized in the Photovoltaic Venture Analysis [2]. This material will be used as needed to identify promising markets. 
Information available in published market studies will be supplemented by a series of interviews with selected companies that are currently active in photovoltaics. These interviews, conducted by SERI staff, will discuss the knowledge and opinions of photovoltaic producers and potential producers regarding international markets today and in the future. These interviews will focus on the marketing problems faced by the industry and the appropriate roles for the federal government in overcoming these problems.

Another source of market information is intended to draw on the past market experiences of the United States in exporting other high technology products. The Illinois Institute of Technology Research Institute (IITRI), under subcontract to JPL, has assembled a panel of experts on export marketing. This panel will identify the marketing problems that are likely to be confronted by U.S. suppliers. Based on their experiences, the panel will suggest how the U.S. government could help photovoltaic companies market internationally and overcome these problems.

Many of the most promising international markets (i.e., water pumping and remote general power systems) are expected to he in developing countries. Developing rountries have unique market characteristics. To examine the problems that will be faced in these markets, a panel of experts on rural development will be assembled by the MIT Energy Laboratory, under subcontract to JPL. The panel will identify the pitfalls that of ten occur in development projects and suggest what types of business and marketing arrangements are likely to be acceptable to developing countries. Previous efforts to introduce new technologies into developing countries will be discussed to suggest the approaches that would be effective for photovoltaics. Of particular interest are the use of demonstration projects and educational programs for encouraging photovoltaic applications. JPL, through selected interviews with organizations and individuals active in international development, will also examine political and social issues relevant to the plan.

The policies of international financial institutions could have a strong influence on the nature and location of international development projects that are initiated and the. constraints within which these projects are conducted. Because a large portion of the potential international market for photovoltaics is believed to be in developing countries, the programs planned by these institutions must be identified and described. Plans and policies of international financial institutions that might finance development projects in which photovoltaic power systems could be used will be reviewed by Strategies Unlimited, under subcontract to SERI. With the advice of international finance experts, a list of significant institutions will be assembled. Through direct contact with these institutions, estimates of the location and types of prnjerts likely to be financed and the opportunities for using photovoltaics in these projects will be made. Private banks have recently become an important source of financing for development projects. The attitudes of both public and private institutions toward photovoltaics will be examined. This task will attempt to determine what government actions would increase the probability that both public and private financial institutions would be receptive to photovoltaic projects.

Another factor that will influence the success of U.S. companies in international markets is the strength of foreign competition. Science Applications, Inc., under subcontract to SERI, will summarize the status of the photovoltaic industry in other countries, particularly Japan, Germany, and France. This summary will address both the technical and market positions of foreign companies in the international market. Support of marketing activities provided by foreign governments will also be considered both to determine the 
relative market position of U.S. companies and to suggest possible U.S. government programs.

Several technical issues are relevant to international markets. JPL will examine the economies of producing photovoltaic modules in foreign countries. This information will provide insights into the attractiveness of turnkey factories located near major markets. Although photovoltaic systems for applications, such as water pumping and remote general power, are already technically feasible, some opportunities for improved system design may exist. JPL, with support for NASA-Lewis Research Center, will identify any development work related to international applications that should be undertaken. NASA-Lewis is in charge of the stand-alone photovoltaic systems program for DOE.

\subsubsection{Step 5: Second ISCWG Meeting; Review Research Results}

SERI and JPL staff will brief the ISCWG on August 6 on results of the analytical tasks. Contractors may be asked to make presentations on specific tasks as appropriate. Discussion and interpretation of results by ISCWG will follow.

\subsubsection{Step 6: Draft Plan}

Based on the results of analytical tasks, the discussions of the ISCWG, and other steps, SERI and JPL will prepare a draft version of the plan for transmittal to members of the ISCWG, interested government agencies, and outside reviewers by September 6, 1979 .

\subsubsection{Step 7: Prepare Final Plan}

Based on comments received from ISCWG and external reviewers, SERI and JPL staff will revise the draft plan and prepare the final plan by October 4, 1979. This final plan will be sent to responsible DOE officials.

\subsubsection{Step 8: Final Plan to Congress}

Following DOE approvals, the Secretary transmits the final plan to the Congress, as required by the Solar Photovoltaic Energy RD\&D Act.

\subsection{STUDY PARTICIPANTS AND MANAGEMENT PLAN}

In order for an international photovoltaic program plan to be useful, a large number of diverse interests must participate in the planning process. Assembling a credible and representative project team is one of the important early priorities of the project. The participants fall into three major groups. The first group includes U.S. government agencies who will play a role in international photovoltaic developments. This group consists of the members of the expanded International Solar Commercialization Working Group plus other interested agencies. As mentioned previously, the role of this group is to provide comments and reviews of all the outputs of the project. 
Photovoltaic and related industries are the second group of participants in the study. The photovoltaic industries are a key participant because the plan affects their corporate strategies; the plan's success depends crucially on their actions. The photovoltaic industry will be involved through a series of interviews with selected companies. The companies to be interviewed include:
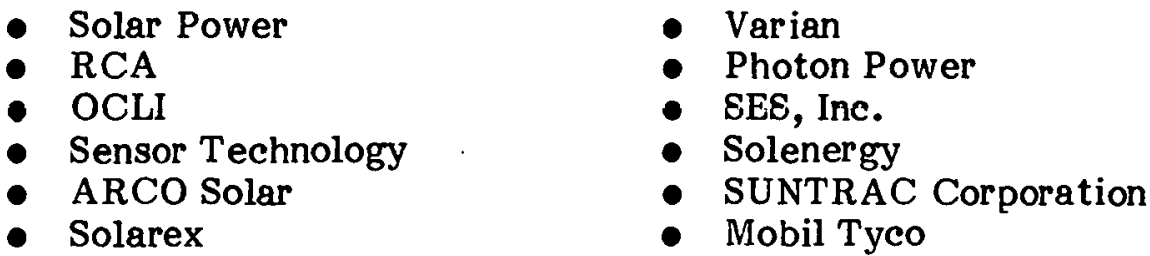

Other industries also have had experience in exporting high-technology U.S. products. The IITRI marketing panel will include several marketing experts with experience in other industries. These are:
Justin Bereny (international market consultant)
Gastone C'hingari (II'l'RI)
William Watt (international market consultant)
Robert McMenamin (international market consultant)
Benjamin Weiner (Probe International)
I. D. Canton (Strategic Decisions)
Charles Gross (Associate Professor, IIT)
Lawrence Wortzel (Professor of Marketing, Boston University)
Dave Morrison (IITRI)

The third group of participants includes economists, policy analysts, engineers, and other scientists currently doing research in the area of photovoltaics. The lead research organization in the effort is the Solar Energy Research Institute (SERI). Dennis Costello, Chief of the Economics and Market Analysis Branch, is the task leader. Professionals from the Policy Analysis Branch, Strategic Planning and Review Branch, Academic and International Programs Division, and Technology Commercialization Division comprise the SERI team. JPL (DOE Photovoltaics Lead Center) will appropriate technical background for the plan as well as photovoltaic market expertise. The final plan will be a joint SERI-JPL publication.

A number of small subcontractors will round out the participants. The MIT Energy Laboratory (Richard Tabors) will provide expertise on rural development problems. Science applications, Inc. (Tom Jaras) will draw on previous market studies to describe international competition. Strategies Unlimited (John Day) brings extensive knowledge of photovoltaic markets and international financing to the project team.

The NASA-Lewis Research Center, in its stand-alone systems role for the photovoltaics program, will provide expert technical information on system design and testing consideratons. NASA-Lewis has fielded a remote village power experiment for the DOE program at the Schuchuli Indian Village in Arizona, and it has a substantial role in AIDsponsored foreign photovoltaic tests and applications.

Finally, other organizations interested in photovoltaics and the international photovoltaic plan will be involved informally. Through informal meetings and correspondence, ideas and comments will be solicited from the Office of Technology Assessment (Henry Kelly), the Solar Lobby (Dennis Hayes), and perhaps the staff of relevant Congressional Committees (after appropriate approvals are received). 


\subsection{SCHEDULE}

The plan is to be delivered to Congress in early November 1979. The final plan will be submitted to DOE for approval in early October. A draft of the plan is scheduled to be reviewed by the interagency committee in early September. The schedule is presented in Table 3-1.

Table 3-1. SCHEDULE

\begin{tabular}{|c|c|}
\hline Milestone & Due Date \\
\hline $\begin{array}{l}\text { 1. Task Preparation } \\
\text { 2. Initial ISCWG Meeting } \\
\text { 3. Visits to individual agencies } \\
\text { 4. Analytical tasks and } \\
\text { 5. Secon for mats } \\
\text { 6. Draft Plan } \\
\text { 7. Final Plan to DOE } \\
\text { 8. Final Plan to Congress }\end{array}$ & $\begin{array}{l}\text { May } 18,1979 \\
\text { May } 18,1979 \\
\text { July } 31,1979 \\
\\
\text { August } 1,1979 \\
\text { August } 6,1979 \\
\text { September } 6,1979 \\
\text { October } 4,1979 \\
\text { November } 5,1979\end{array}$ \\
\hline
\end{tabular}

\subsection{BUDGET}

As discussed in Section 3.3, the two major organizations involved in preparing the plan are SERI and JPL. Each organization will have its own budget; no funds will be transferred from DOE to either organization or between JPL and SERI. The funding is expected to come from reprogramming existing funds at SERI and from Lead Center funds at JPL. Table 3-2 presents a summary of the budget for SERI's effort in the plan.

Table 3-2. SERI BUDGET SUMMARY

1. Professional and Support Labor (15.5 man-months) (D. Costello, D. Posner, R. Koontz, J. Ashworth, B. Spongberg, P. Thompson, P. Heiferling)

$\$ 94,730$

2. Subcontracts (SAI, Strategies Unlímited)

3. Other Direct Costs (Travel, Printing, Miscellaneous Purchases)

4. Materials Handling and Fee

Total SERI Budget:

The JPL budget includes approximately 12 man-months of effort plus three man-months from the Massachusetts Institute of Technology Energy Laboratory. The major subcontract is $\$ 125,000$ for the IITRI study on industry viewpoints. The JPL effort totals 
$\$ 200,000$. The MIT effort totals $\$ 19,000$. A summary of the JPL and MIT budgets is shown in Table 3-3.

Table 3-3. JPL AND MIT BUDGET SUMMARY

\section{A. JPL Budget}

1. Professional and Support Labor (12 man-months) (P. Carpenter, L. Perelman, R. Easter, S. Forman, $\$ 70,000$ and selected others)

2. Subcontract

(ITRI)

125,000

3. Other Direct Costs

(Truvel, reproduction, misçellanøous)

TOTAL $\$ 200,000$

B. MTT Energy Laboratory

1. Professional Labor (3 man-months)

$\$ 17,000$

(R. Tabors, T. Neff, D. Smith, consultant)

2,000

2. Other Direct Costs

$\$ 18,000$ 


\section{SECTION 4.0}

\section{OBJECTIVES OF THE INTERNATIONAL PLAN}

The Solar Photovoltaic Energy RD\&D Act of 1978 found "Photovoltaic energy systems are economically competitive with conventional energy resources for a wide variety of applications in many foreign nations at the present time, and will find additional applications with continued cost reductions" [1, Sec. 2(a)]. Remote pumping, refrigeration, lighting, and communication applications are examples of these markets.

Foreign sales of photovoltaic systems by U.S. firms currently dominate commercial sales and are expected to continue to do so until larger U.S. grid-connected applications become economically feasible. Foreign markets are the key bridge markets between current high price remote markets and large energy-displacing markets in the U.S.

Government purchases of modules or systems by themselves are unable to provide the volume necessary to sustain the industry and reduce system costs to the level necessary to compete with utility power. Private domestic sales are unable to act in this role due to the limited number of cost-effective remote applications in the United States.

Also; it is widely recognized that adequate energy supplies, at reasonable costs, are critical to the development process within many nations. The use of photovoltaics to provide village power or agricultural pumping may help to ease dependence on costly and vulnerable fossil-fuel supplies and could alleviate some environmental problems (e.g., the increasing desertification of land due to the exploitation of area forests for fuel) [9].

Further, it is agreed by most government and industry representatives that photovoltaic sales in developing nations will expand significantly over the next decade. This market expansion is likely to occur with or without the assistance of the U.S. government. However, government actions have the potential to accelerate the pace of this expansion.

\subsection{STATEMENT OF OBJECTIVE}

For the reasons listed above, it is appropriate for the U.S. government to play a role in ensuring that these key international markets develop as rapidly as possible. Therefore, the primary objective of the international photovoltaic plan is to accelerate the widespread use of photovoltaic systems in international markets.

In achieving this objective, a number of national and international benefits will result. The primary benefit is to maintain, stabilize, and foster the expansion of the U.S. photovoltaic industry by facilitating worldwide exports. Removal or circumvention of current barriers to international sales may provide a substantial stabilizing influence on the photovoltaic industry as it encounters the stresses of rapid technological change and cost reduction.

The second benefit is a contribution to the economic, political, and social advancement of developing countries. As mentioned earlier, steep price increases for petroleum in oil-deficient developing countries have slowed progress toward development goals, and have eroded or neutralized the gains made by the countries themselves or through assistance provided by the United States and other donors. Photovoltaic applications for these nations can have especially important development benefits. 
$\stackrel{x=-1}{i=-i !}$

The third benefit is to reduce the rate of growth in the worldwide demand for oil. Just as the domestic photovoltaic program will lead eventually to fossil-fuel displacement, so too can the international use of photovoltaics benefit other nations through the displacement of grid-connected power as well as through the substitution of photovoltaic devices for diesel or gas-generated electric power. Other benefits associated with oil displacement are:

- an easing of the competition between major consumers over limited oil supplies;

- a reduction in the long-term upward pressure on oil prices;

- a reduction in the balance-of-payment deficits of many developed and developing countries; and

- a lessening of the harmful environmental effects from continued or accelerated traditional fuel use.

The fourth benefit of meeting the plan's objective is improving the U.S. balance of trade position. Traditionally, the United States has maintained its trade position in the world economy through the export of high technology products and production equipment. Since the rapid rise in world oil prices of the $1970 \mathrm{~s}$, the United States has suffered damaging trade deficits. Widespread world sales of photovoltaics would continue the U.S. tradition of high technology trade as a means of reducing the deficit.

If designed properly, meeting the objective of the plan can also encourage international scientific and technological cooperation through the cooperative development and demonstration of photovoltaic devices. The benefit is supportive of previous legislation in the nonnuclear technology field and recent international agreements, such as the Bonn Summit Conference of 1978.

\subsection{NUMERICAL OBJECTIVES FOR THE INTERNATIONAI, PIAAN}

For the plan to be successful, agencies will have to coordinate their efforts, provide for management, and monitor and assess progress toward reaching the objective.

The legislation establishes the following quantitative objectives for the domestic photovoltaic industry.

- Double the production of photovoltaic energy systems each year during the decade starting with FY79, measured by the peak generating capacity of the systems produced, $S O$ as to reach a total annual U.S, production of solar photovoltaic energy systems of approximately 2 million $\mathrm{kWp}$ and a total cumulative production of such systems of approximately four million $\mathrm{kWp}$ by FY88;

- Reduce the average cost of installed solar photovoltaic energy systems to $\$ 1 /$ Wp by FY88; and

- Stimulate the purchase by private buyers of at least 90 percent of all solar photovoltaic energy systems produced in the United States during fiscal year 1988 [1, Sec. 2(a)]. 
The international plan directly supports the first numerical target of the act and indirectly supports the second and third. If these legislative production goals are to be met, then rapid growth in international sales will be essential. Available market information indicates that the production goals, as currently stated in the Act, are very ambitious. The plan's objective of accelerating the widespread use of photovoltaic systems in international markets will be measured by the number of photovoltaic systems sold in those markets. It is the goal of the international plan to contribute to the expansion of photovoltaic production such that between $60 \%$ and $75 \%$ of the U.S. photovoltaic systems produced are sold in foreign markets between FY79 and FY85. During the period FY85-FY88, sales of photovoltaics to U.S. markets should expand dramatically. When this expansion occurs, the key role of international markets as a bridge to U.S. grid markets will be realized. Therefore, it is appropriate that the quantitative targets of the international plan be stated for the FY79-FY85 time period. 


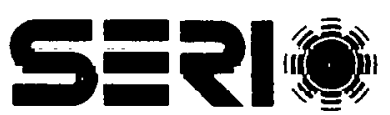




\section{SECTION 5.0}

\section{STRATEGIES AND TACTICS}

The most important part of the planning process will be translating the plan objective into effective strategies and tactics. Strategies and tactics selected for the final plan must be responsive not only to the plan objective but also to the unique contributions that different agencies can make. These strategies and tactics must also recognize the technical, marketing, and business circumstances of the photovoltaic industry, plus the influences that various federal agencies and programs can have on these circumstances. The planning process and analytical tasks described previously are intended to ensure that the plan recommends strategies and tactics that are both needed and feasible.

Several sources have already identified federal programs that could accelerate solar exports and photovoltaics in particular $[2,10,11,12]$. Preliminary interviews by the project team with the photovoltaic industry and U.S. government agencies plus other initial findings of the analytical tasks suggest strategies and tactics that could be included in the plan.

This section describes seven general strategies that will be addressed in the final plan. These seven strategies are believed to bracket the range of approaches to facilitating the development of foreign markets for photovoltaics. In the final plan, these strategies will lead to the choice of specific tactics. In this section, no attempt is made to specify, in detail, tactics that will be used to implement the strategies. Some examples of tactics are given below to illustrate the types of actions that will be considered. Tactics contained in the final plan will be action oriented; that is, they will suggest certain actions which should be taken by selected agencies at specific times and with associated budgets.

In addition to suggesting strategies and tactics, the final plan will address the problem of timing. Strategies and tactics will be considered in light of the DOE domestic photovoltaic program and planned federal procurements of photovoltaic systems. The plan will attempt to coordinate with and complement other photovoltaic programs so that these programs will positively influence the development of the photovoltaic industry.

\subsection{PHOTOVOLTAIC SYSTEM DEMONSTRATIONS}

Demonstration of photovoltaic systems is probably the most powerful strategy for proving photovoltaic system capabilities and stimulating future sales. There are many tactics that could be used to demonstrate photovoltaic technology in foreign markets. Bilateral agreements with selected countries could be used to field projects, or the U.S. government could demonstrate systems through AID programs. Demonstrations can help companies develop contacts with distributors, installers, and maintenance organizations. Improvements in system designs can also be accomplished through demonstrations. Both suppliers and potential users could gain valuable experience with photovoltaic systems in the international market. The Photovoltaic RD\&D Act of 1978 placed emphasis on demonstrations of the requirements for the international plan. Demonstrations will represent the key strategy of the plan and will require the majority of the available resources. 


\subsection{SYSTEMS DEVELOPMENT}

Photovoltaic systems for international markets can be assembled currently from off-theshelf components. In some cases, however, improvements in system design and reductions in cost might result from modifications in selected components. The DOE photovoltaics program is investing substantial resources in the development of new components for use in domestic systems. A strategy that will be included in the international plan is to conduct development work relevant to systems which have international market potential. For example, improved pumps or control systems might be developed for small-scale pumping systems. Needs for development work will be identified and, if needed, development projects will be recommended.

\subsection{INFORMATION GATHERING: SUPPLIER ASSISTANCE}

This strategy is to educate U.S. companies concerning the nature of foreign markets and to assist U.S. companies in making foreign sales. One of the major obstacles to expanding foreign sales is that little is known about foreign markets and how sales can be made. A tactic to overcome this problem could be to support country-specific market studies that describe the types of applications, possible distribution channels, financing, and government regulations and programs that exist in a given country, and make these studies available to the entire industry. Another tactic could be to directly support marketing activities of photovoltaic companies and allow companies to conduct their own market research and develop their own contacts. Periodic workshops, perhaps coordinated by the Department of Commerce, could be held for U.S. suppliers to present new market information and assist the industry in developing marketing strategies. Many other tactics for information gathering and supplier assistance could be developed that will strengthen the positions of U.S. companies in international markets.

\subsection{INFORMATION DISSEMINATION: MARKET ASSISTANCE}

Just as U.S. suppliers need to know how and where photovoltaic systems can be effectively used, potential customers need to understand the capabilities of photovoltaic systems. Many promising applications, such as photovoltaic pumping systems, village power systems, and educational television systems, represent new uses of power-about which little is known. In developing countries, officials responsible for agriculture, electric power, and rural development could be familiarized with the economics of photovoltaic systems in promising applications. International financial institutions and private financiers also could be informed of what photovoltaic systems can do. Before photovoltaics are likely to be sold on a large scale in foreign countries, these countries and institutions must be convinced of their value. Other tactics include solar trade fairs sponsored by the Department of Commerce and the education of engineers and technicians on photovoltaic system technology. Tours of U.S. photovoltaic demonstration projects and manufacturers could be sponsored by DOE.

\subsection{ADMNISTRATIVE ACTIONS}

Numerous regulations influence the export of U.S. products. These include such policies as export licensing, which requires the reporting of all foreign sales above a certain quantity for products on the defense control list. Until recently, all international sales of photovoltaics had to comply with the export licensing policy. Other regulations include 
international tariff policies and antitrust policies that govern the sale of U.S. products abroad. Regulations covering photovoltaic exports will be reviewed to identify any unnecessary obstacles and to suggest how sales might be facilitated by administrative changes in regulatory policies.

\subsection{FINANCIAL INCENTIVES}

There are numerous types of financial incentives that might accelerate the development of international markets for photovoltaics. These incentives could be used to lower the price of photovoltaic systems to end users and to increase the availability and lower the risks of financing for photovoltaic systems. For example, special tax credits could be made available for foreign photovoltaic sales, or loans could be guaranteed. Accelerated depreciation write-offs could be allowed for manufacturing facilities servicing foreign markets. Many other financial incentive options exist. The plan will attempt to identify those that would have the greatest impact on foreign market developments at the least cost.

\subsection{MONTORING, ASSESSMENT, AND COORDINATION}

The strategies cited above will lead to individual agency programs that could facilitate the international market. One of the key strategies of the international plan will be to coordinate these individual programs to monitor their impacts and to assess their effectiveness. The international plan must be more than a set of actions that are adopted and then forgotten. If the plan's objective is to be realized, a strategy for following up on the actions taken, improving these actions, and adopting new actions is needed. Ensuring that an effective and continuing program for international market development is pursued will be basic to a successful plan. 


\section{S=PI絭}




\section{SECTION 6.0}

\section{REPERENCES}

1. Solar Photovoltaic Energy Research, Development, and Demonstration Act of 1978; Public Law 95-590: November 4, 1978.

2. Costello, Dennis; Posner, David; Schiffel, Dennis; Doane, James; Bishop, Charles. Photovoltaic Venture Analysis: Final Report. Golden, CO: Solar Energy Research Institute, SERI/TR-52-040, July 1978.

3. U.S. Department of Energy. Export Potential for Photovoltaic Systems: Preliminary Report. Washington, DC: U.S. DOE-Solar Applications; April 1979.

4. BDM Corporation. Photovoltaic Power Systems Market Identification, Draft. Washington, DC: U.S. Department of Energy; May 1977; November 1977; February 1978.

5. Intertechnology Solar Corporation. Photovoltaic Energy Technology Market Analysis; Draft. Washington, DC: U.S. Department of Energy; January 1978.

6. Booz Allen. Assessment of Solar Photovoltaic Industry, Market, and Technologies, draft report to DOE. Bethesda, MD; September 1978.

7. Aerospace Corporation. Mission Analysis of Photovoltaic Solar Energy Conversion: Volume II, Survey of Near-Term Civilian Applications in the United States. Washington, DC: Energy Research and Development Agency; March 1977.

8. Drucker, Peter F. Management: Tasks, Responsibilities, Practices. New York, NY: Harper and Row; 1974.

9. Revelle, Roger. Energy Sources for Rural Development. LaJolla, CA: University of California; January 1979.

10. Solar Energy Domestic Policy Review. International Panel Policy Options Paper. Washington, D.C.: U.S. DOE; August 23, 1978.

11. Solar Energy Research Institute. DOE Solar Export Opportunities Workshop; Golden, CO: Solar Energy Research Institute; April 1979.

12. Jaras, Thomas F.; Mansoor, Yardena. U.S. Institutional Factors in the Export of Photovoltaics; Draft. McLean, VA: Science Applications, Inc.; December 1978. 


\section{S=Pl部}




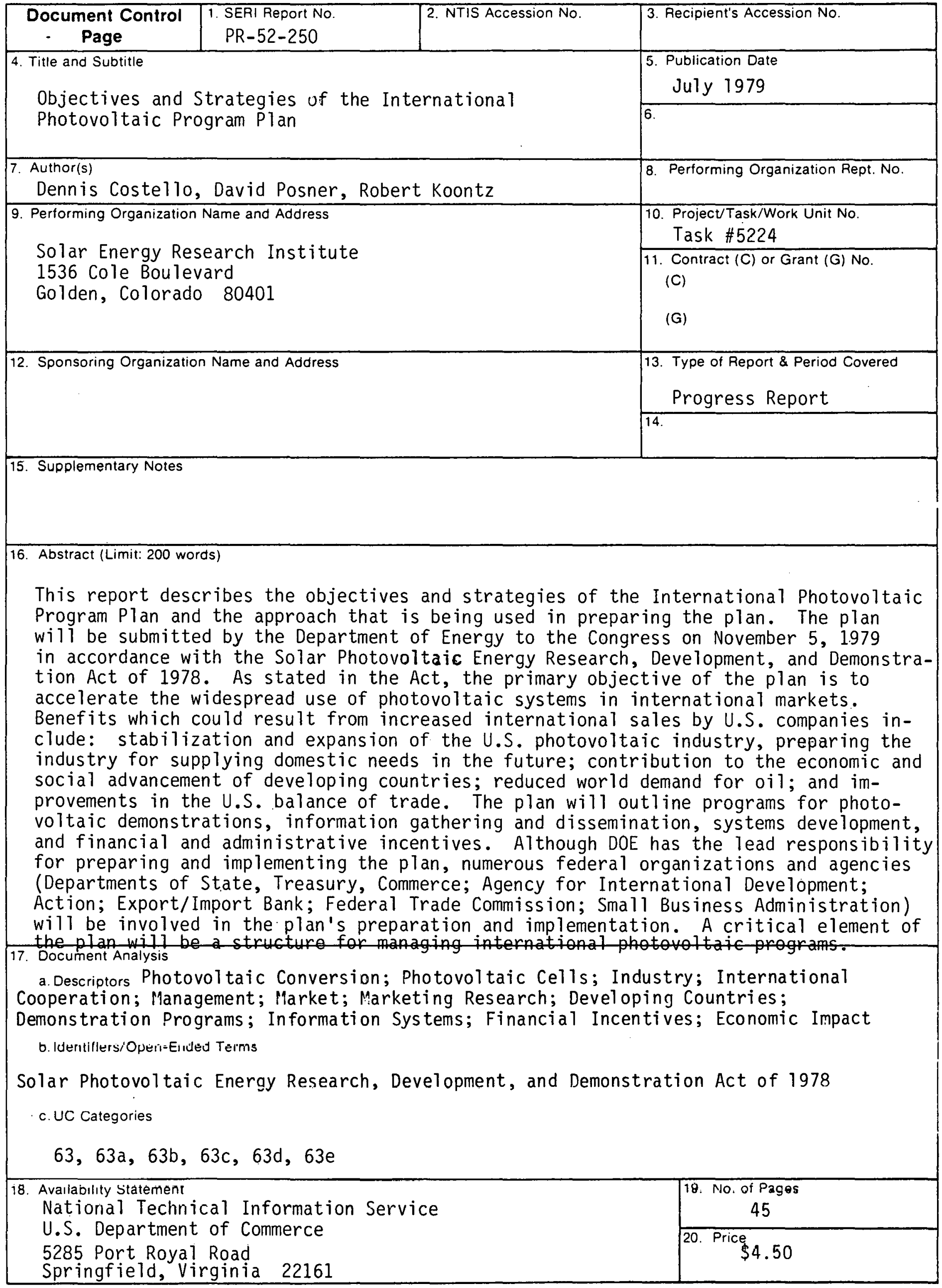

